\title{
Characterization of selected cotton growing soils of Wardha district, Maharashtra
}

NILIMA S. SADANSHIV, N.S. WAGH AND SONAL I. THELKAR

Received : 08.02.2017; Revised : 08.05.2017; Accepted : 21.05.2017

\section{MEMBERS OF RESEARCH FORUM:}

Corresponding author : NILIMA S. SADANSHIV, Department of Soil Science and Agricultural Chemistry, Dr. Panjabrao Deshmukh Krishi Vidyapeeth, AKOLA (M.S) INDIA Email: nil.sadanshiv@gmail.com

Co-authors : N. S. WAGH AND SONAL I. THELKAR, Department of Soil Science and Agricultural Chemistry, Dr. Panjabrao Deshmukh Krishi Vidyapeeth, AKOLA (M.S) INDIA Email: nwagh98@gmail.com; sonal.kalpana@gmail.com

\section{Summary}

Nine cotton growing soils located on Deoli, Wardha, Karanja, Ashti tehsils of Wardha district, Maharashtra was characterized. Horizon-wise soil samples were collected and studied for morphological, physical and chemical properties. The soils were brown to very dark gray in colour, shallow $(31 \mathrm{~cm})$ to very deep $(150 \mathrm{~cm})$, silty clay loam to clay in texture, imperfectly to well drained and most of the soils had sub-angular blocky structure in the B horizon with a few of them having pressure faces and slickensides. The soil had mildly alkaline to strongly alkaline, all these soils were non-saline, organic carbon was low and decreased with depth, high CEC with calcium as dominant cation on exchange complex. These soils were classified as Typic Haplusterts, Typic Calciusterts, Typic Haplustepts, Typic Calciustepts and Lithic Ustorthents at subgroup level.

Key words : Cotton growing soils, Soil characterization, Classification

How to cite this article : Sadanshiv, Nilima S., Wagh, N.S. and Thelkar, Sonal I. (2017). Characterization of selected cotton growing soils of Wardha district, Maharashtra. Asian J. Soil Sci., 12 (1) : 174-180 : DOI : 10.15740/HAS/AJSS/12.1/174-180. 